Journal of

Latin American

Studies

volume 49 : part 3 : August 2017

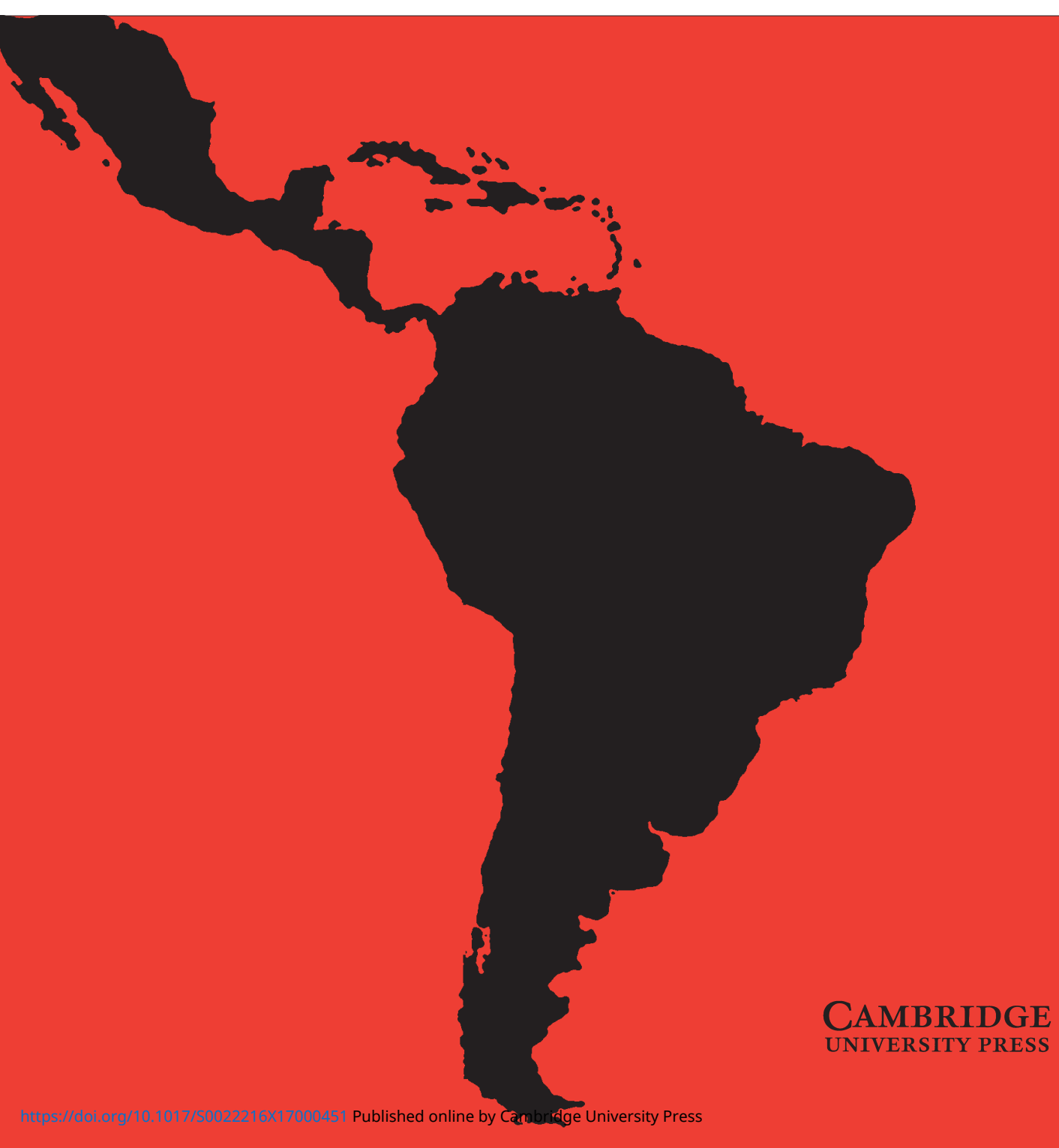


EDITORIAL BOARD

Edmund Amann

Leiden University, Netherlands

Andrew Canessa

University of Essex

Paulo Drinot

Institute of the Americas, University College London

Tanya Harmer

LSE

Andrew Hurrell

University of Oxford

Alejandra Irigoin

LSE

Gareth A. Jones

LSE

Peter Kingstone

King's College London

Nina Laurie

University of St Andrews

\section{INTERNATIONAL ADVISORY BOARD}

Marianne Braig

Institute for Latin American Studies, Berlin

Benedicte Bull

University of Oslo

Catherine Conaghan

Queen's University, Kingston, Ontario

Marcos Cueto

Casa de Oswaldo Crus, Rio de Janeiro

Brodwyn Fischer

University of Chicago

Jonathan A. Fox

American University

Zephyr Frank

Stanford University

Peter Fry

Universidade Federal do Rio de Janeiro
Sian Lazar

University of Cambridge

Fiona Macaulay

University of Bradford

Maxine Molyneux

Institute of the Americas, University College London

Leigh Payne

University of Oxford

Diego Sánchez-Ancochea

University of Oxford

Benjamin T. Smith

University of Warwick.

Peter Wade

University of Manchester

Graham Denyer Willis

University of Cambridge

\section{COPY EDITOR}

Virginia Catmur

EDITORIAL ADMINISTRATOR

Celia Barlow, Institute of Latin American Studies, University of London

SPANISH TRANSLATOR (ABSTRACTS)

Carlos Y. Flores, Universidad Autónoma del Estado de Morelos, Mexico

PORTUGUESE TRANSLATOR (ABSTRACTS)

Vinicius Honorato, London

(C) Cambridge University Press 2017

\section{SUBSCRIPTIONS}

The Journal of Latin American Studies (ISSN 0022-2I6X) is published four times a year with four parts forming a volume in February, May, August and November by Cambridge University Press, The Edinburgh Building, Shaftesbury Road, Cambridge CB2 8RU/Cambridge University Press, I Liberty Plaza, Floor 20, New York, NY I0006, USA. Single parts are f,IO2.00 net (US\$ 179.00 in the US, Canada and Mexico) plus postage. The subscription price, which includes postage of volume 49 (excluding VAT), is $£ 368.00$ (US\$ 645 . 00 in the US, Canada and Mexico) for institutions (print and electronic) and $f_{65.00}$ (US\$ IO2.00) for individuals (print only) ordering direct from the publishers and certifying that the journal is for their personal use. A special rate is available for students $(f, 30.00$, US $\$ 47.00)$. EU subscribers (outside the UK) who are not registered for VAT should add VAT at their country's rate. VAT-registered subscribers should provide their VAT registration number. Orders, which must be accompanied by payment, may be sent to a bookseller or to the publishers: Cambridge University Press, Journals Fulfilment Department, UPH, Shaftesbury Road, Cambridge CB2 8BS, UK and in the USA, Canada and Mexico, Cambridge University Press, Journals Fulfillment Department, I Liberty Plaza, Floor 20, New York, NY 10006, USA. Japanese prices for institutions are available from Kinokuniya Company Ltd, P.O. Box 55, Chitose, Tokyo I56, Japan. Prices include delivery by air. Periodical postage paid at New York, NY and additional mailing offices.

POSTMASTER: Send address changes to Cambridge University Press, Ioo Brook Hill Drive, West Nyack, New York 10994-2I33.

INTERNET ACCESS: This journal is included in the Cambridge Journals Online service, which can be found at www.cambridge.org/LAS. For further information on other Press titles, access www.cambridge.org. 


\section{Journal of}

Latin American

Studies

VOLUME 49 PART 3 AUGUST 2017

\section{EDITORS}

P A U L O D R I N O T

Senior Lecturer in Latin American History, Institute of the Americas, University College London

GARETH A. JONES

Professor of Urban Geography, London School of Economics \& Political Science

S I A N L A Z A R

Senior Lecturer in Social Anthropology, University of Cambridge

D IE G O S Á N C H E Z - A N C O C H E A

Associate Professor in the Political Economy of Latin America, University of Oxford

\section{CAMBRIDGE}

UNIVERSITY PRESS 


\section{Contents}

\section{ARTICLES}

Bolivian Tariff Policy during the Late Nineteenth and Early Twentieth Centuries: High Average Tariff and Unbalanced Regional Protection

JOSÉ ALEJANDRO PERES-CAJÍAS

Poor in Numbers: A Contribution to a Social History of Social Statistics in Contemporary Argentina

CLAUDIA DANIEL AND GABRIEL VOMMARO

Drug Wars: Revolution, Embargo, and the Politics of Scarcity in Cuba, 1959-1964

JENNIFER LAMBE

Venturing Abroad: The Internationalisation of Mexican Banks Prior to the 1982

Crisis

SEBASTIA N A L VAREZ

Accumulation by Forced Removal: The Thinning of Rio de Janeiro's Favelas in Preparation for the Games

JAMES FREEMAN AND MARCOS BURGOS

Internal Movement Transformation and the Diffusion of Student Protest in Chile

IN DIRA PALACIOS-VALLADARES

'God Even Blessed Me with Less Money': Disappointment, Pentecostalism and the Middle Classes in Brazil

GEORGE ST. CLAIR

\section{COMMENTARY}

Women and Legal Pluralism: Lessons from Indigenous Governance Systems in the Andes 


\section{BOOK REVIEWS}

Ben Ross Schneider (ed.), New Order and Progress: Development and Democracy in Brazil, reviewed by Anthony W. Pereira

Eric Hershberg and William M. LeoGrande (eds.), A New Chapter in US-Cuba Relations: Social, Political and Economic Implications, reviewed by Marie Laure Geoffray

Analiese Richard, The Unsettled Sector: NGOs and the Cultivation of Democratic Citizenship in Rural Mexico, reviewed by John Gledhill

Manuel Llamojha Mitma and Jaymie Patricia Heilman, Now Peru is Mine: The Life and Times of a Campesino Activist, reviewed by Javier Puente

Tammy L. Lewis, Ecuador's Environmental Revolutions: Ecoimperialists, Ecodependents, and Ecoresisters, reviewed by Jennifer Collins

Tianna S. Paschel, Becoming Black Political Subjects: Movements and Ethno-Racial Rights in Colombia and Brazil, reviewed by David Lehmann

Erik Ching, Stories of Civil War in El Salvador: A Battle over Memory, reviewed by Jenny Pearce

Sandra Brunnegger and Karen Ann Faulk (eds.), A Sense of Justice: Legal Knowledge and Lived Experience in Latin America, reviewed by Ton Salman

Anita Ferrara, Assessing the Long-term Impact of Truth Commissions: The Chilean Truth and Reconciliation Commission in Historical Perspective, reviewed by Cath Collins

Luis van Isschot, The Social Origins of Human Rights: Protesting Political Violence in Colombia's Oil Capital, I9Ig-20Io, reviewed by Brett Troyan

John Abromeit, Bridget María Chesterton, Gary Marotta and York Norman (eds.), Transformations of Populism in Europe and the Americas: History and Recent Tendencies, reviewed by Jorge A. Nállim

Paulo Fontes, Migration and the Making of Industrial São Paulo, reviewed by Ángela Vergara

Aragorn Storm Miller, Precarious Paths to Freedom: The United States, Venezuela, and the Latin American Cold War, reviewed by Patrick Iber

Laura Prado Acosta, Los intelectuales del Partido Comunista: Itinerario de Héctor Agosti (1930-1963), reviewed by Hernán Camarero

John A. Gronbeck-Tedesco, Cuba, the United States, and Cultures of the Transnational Left, 1930-1975, reviewed by Aldo Marchesi

Edward Beatty, Technology and the Search for Progress in Modern Mexico, reviewed by Thomas Rath

Miguel Fuentes (ed.), Rapa Nui y la Compañia Explotadora, I895-1953, reviewed by Alberto Harambour

Charles F. Walker, The Tupac Amaru Rebellion, reviewed by Anthony McFarlane

Nora E. Jaffary, Reproduction and its Discontents in Mexico: Childbirth and Contraception from I750 to Igos, reviewed by Elizabeth O'Brien

Jason McGraw, The Work of Recognition: Caribbean Colombia and the Postemancipation Struggle for Citizenship, reviewed by Marcela Echeverri

Ana María Ochoa Gautier, Aurality: Listening and Knowledge in Nineteenth-Century Colombia, reviewed by Anna Cant

John M. D. Pohl and Claire L. Lyons (eds.), Altera Roma: Art and Empire from Mérida to Mexico, reviewed by Harriet Smart

Martha Few, For All of Humanity: Mesoamerican and Colonial Medicine in Enlightenment Guatemala, reviewed by Pablo F. Gómez 
Victor M. Uribe-Uran, Fatal Love: Spousal Killers, Law, and Punishment in the Late Colonial Spanish Atlantic, reviewed by Alexander L. Wisnoski III

Zephyr L. Frank, Reading Rio de Janeiro: Literature and Society in the Nineteenth Century, reviewed by Maria-Aparecida Lopes

Phillip Penix-Tadsen, Cultural Code: Video Games and Latin America, reviewed by Edward King 